\title{
Determinant of Health Services Utilization by Persons with Disabilities in Palembang City
}

\author{
Herawati Idris ${ }^{1,{ }^{*}}$, Tilla Safitri $^{1}$, Dian Safriantini ${ }^{1}$, and Inoy Trisnaini ${ }^{2}$ \\ ${ }^{1}$ Department of Health Policy and Administration, Faculty of Public Health, Universitas Sriwijaya, \\ Indonesia \\ ${ }^{2}$ Department of Health Environment, Faculty of Public Health, Universitas Sriwijaya, Indonesia
}

\begin{abstract}
The issue of PWDs (Person with Disabilities) is a human right issue. Stigma and discrimination from the community as well as health workers often become obstacles for PWDs in utilization of health services. The study aimed to determine the determinants of health services by PWDs in the city of Palembang. This study used cross sectional study design. The samples of this study were 103 samples of PWDs selected by cluster random sampling. The analysis methods of this study were bivariate using chi-square as well as multivariate test using multiple logistic regression tests. The study found that PWDs who utilize health care services are female, high income, easy access to health services, low health care cost and a positive attitude towards services health. The most influential variables on the utilization of health services is a positive attitude towards health services. The utilization of health services by PWDs in Palembang city has not optimal. It is hoped the goverrment will review the existing in health services so that a friendlier situation and region of PWDs can be created.
\end{abstract}

\section{Introduction}

The issue of PWDs (Persons with Disabilities) is a human rights issue. Often PWDs get stigma and discrimination; this is the reason why PWDs are excluded from education, employment, health services and other public services. PWDs are persons with limited activity in performing activities or actions as well as persons having a discrepancy that occurs in the function or structure of the body. [1] In fact, PWDs often do not get the necessary health care. Children with disabilities tend to be out of school compared to children who are not. PWDs are more likely to be unemployed than people who are not . PWDs are vulnerable to poverty. [2]

As many as one billion or about $15 \%$ of the world's population experience disability. Among 110-190 million adults have significant functional difficulties. Approximately $82 \%$ of disabilities are in developing countries and live below the poverty line and often limited

\footnotetext{
*Corresponding author: haera@fkm.unsri.ac.id
} 
access to PWDs, whether access to health, education, training and decent work is due to poverty andsocial exclusion from non-disadvantaged community's PWDs.[3]

Indonesia is the country with the highest number of persons with disabilities in the Southeast Asia region. The number of estimates of the prevalence of PWDs in Indonesia is $12.15 \%$, which is divided into severe disabilities by $1.87 \%$ and moderate disability by $10.29 \%$. Provinces with the highest number of PWDs are West Sumatra, East Nusa Tenggara and South Sulawesi. The number of women with disabilities in Indonesia is higher than the men's. The number of women with disabilities is $53.37 \%$ while the number of men with disabilities is $46.63 \%$. Almost $50 \%$ of people with disabilities never or did not graduate from elementary school.[4]The types of disability in Palembang city based on the Palembang City Social Service Data are physical disability, mental disability, blind, speech impaired and double disability.[5] PWDs get the same opportunities and treatment to get information and health services in accordance with health service standards.[6] With the convention on the rights of PWDs, it is expected to improve the welfare, health, justice and other rights. The purpose of this study was to find out the determinants of health services utilization by persons with disabilities in the city of Palembang.

\section{Materials and Methods}

Design in this study was cross sectional with quantitative method. The population in this study was severe persons with severe disability who have the assistance of people with severe disability in Palembang city. The samples in this study were 103 severe persons with severe disability who received the assistance of people with severe disability in Palembang city selected by cluster random sampling. The cluster selected were 7 sub-district clusters, namely Ilir Timur I Sub-District, Sako Sub-district, Kemuning Sub-District, Sukarami SubDistrict, Ilir Barat I District, Sematang Borang Sub-District and Kalidoni Sub-District. The analysis in this study used statistical software with univariate analysis, bivariate using chisquare and multivariate using multiple logistic regressions. Sample inclusion criteria are PWDs or parents or families with disabilities who are willing to become respondents and have a companion for PWDs who are difficult to communicate. While the sample exclusion criteria are disabled persons who have died or those who have moved or whose address are unknown. The independent variables in this study were age, gender, income, disability, health insurance, access to health services, health care costs and attitudes.

\section{Results dan Discussions}

The utilization of health services by persons with disabilities in health services utilization by PWDs is $47.6 \%$. The percentage of female is $52.4 \%$, with age $\leq 30$ years (young) is $76.7 \%$, with income $\geq 2.600 .000$ (high) is $34.0 \%$, with single disability category is $47.6 \%$, and have health insurance is $91.3 \%$, with access to easy health services is $64.1 \%$, with cheap health service costs is $86.4 \%$ and positive attitude is $67.0 \%$. 
Table 1.Determinants of the Utilization of Health Services by Persons with Disabilities in Palembang City

\begin{tabular}{|c|c|c|c|c|}
\hline \multirow[t]{2}{*}{ Variable } & \multicolumn{2}{|c|}{$\begin{array}{c}\text { Health Services } \\
\text { Utilization }\end{array}$} & \multirow[t]{2}{*}{ p-value } & \multirow[t]{2}{*}{ PR (95\% CI) } \\
\hline & Yes & No & & \\
\hline \multicolumn{5}{|l|}{ Age } \\
\hline Young & 41 & 38 & \multirow{2}{*}{0.173} & $1.557(0.851-2.849)$ \\
\hline Old & 8 & 16 & & \\
\hline \multicolumn{5}{|l|}{ Gender } \\
\hline Female & 32 & 22 & \multirow{2}{*}{0.022} & $1.708(1.096-2.661)$ \\
\hline Male & 17 & 32 & & \\
\hline \multicolumn{5}{|l|}{ Income } \\
\hline High & 25 & 10 & \multirow{2}{*}{0.001} & $2.024(1.378-2.971)$ \\
\hline Low & 24 & 44 & & \\
\hline \multicolumn{5}{|l|}{ Disability } \\
\hline Single Disability & 24 & 25 & 0.940 & $1.058(0.705-1.587)$ \\
\hline DoubleDisability & 25 & 29 & & \\
\hline \multicolumn{5}{|l|}{ Health Insurance } \\
\hline Yes & 47 & 47 & \multirow{2}{*}{0.165} & $2.250(0.652-7.766)$ \\
\hline No & 2 & 7 & & \\
\hline \multicolumn{5}{|l|}{$\begin{array}{l}\text { Access to health } \\
\text { services }\end{array}$} \\
\hline Easy & 38 & 28 & \multirow{2}{*}{0.012} & $1.937(1.132-3.313)$ \\
\hline Difficult & 11 & 26 & & \\
\hline \multicolumn{5}{|l|}{ Health services cost } \\
\hline Cheap & 37 & 52 & \multirow{2}{*}{0.005} & $0.485(0.350-0.672)$ \\
\hline Expensive & 12 & 2 & & \\
\hline \multicolumn{5}{|l|}{ Attitude } \\
\hline Positive & 42 & 27 & \multirow{2}{*}{0.000} & $2.957(1.488-5.875)$ \\
\hline Negative & 7 & 27 & & \\
\hline
\end{tabular}

Table 1. shows that PWDs using the majority of health services are young, women, and having high income, single disability, health insurance, easy access to health services, expensive health care costs and positive attitudes. Based on the results of crosstabulation analysis, variables that have significant relationship with the utilization of health services by PWDs are gender (female), income (high), access to health services (easy), health service costs (low) and attitude (positive).

Table 2. Multivariate Analysis of Determinants of the Use of Health Services by Persons with Disabilities in Palembang City

\begin{tabular}{|c|c|c|}
\hline Variable & p-value & PR (95\% CI) \\
\hline Age & 0.024 & $4.218(1.212-14.681)$ \\
\hline Gender & 0.013 & $3.789(1.325-10.828)$ \\
\hline Access to health servoces & 0.014 & $4.267(1.349-13.497$ \\
\hline Attitude & 0.004 & $5.780(1.752-19.075)$ \\
\hline Disability & 0.130 & $2.259(0.787-6.483)$ \\
\hline Health services cost & 0.057 & $0.126(0.015-1.063)$ \\
\hline Income & 0.054 & $2.904(0.980-8.603)$ \\
\hline
\end{tabular}

Table 2. shows factors affecting the utilization of health services by PWDs. The results of utilization of health services by PWDs are most influenced by attitudes. A positive attitude has an effect of 5.78 times on health care utilization, with confidence intervals 
(95\% CI 1.75-19.07). This means that a positive attitude towards health services has a 5.78 times chance to utilize health services. Counfounding variables include disability, health care costs and income.

This study aimed to determine the determinants of the utilization of health services by PWDs in the city of Palembang. The result of descriptive analysis shows that health service utilization is $47.6 \%$. Health care utilization is influences by gender, income, access to health care, the cost of health care and attitude. The results of the analysis show that the variable related to the utilization of health services is gender. The majority who utilize health services are women. Utilization of male health services is lower than women.[7] Demand for women to health services is higher than men.[8] Women are highly utilizing health services than men. Women are more likely to utilize preventive health services compared to men. Basically women are more susceptible to disease than men so women often visit health services compared to men. $[9,10]$ Men are more likely to receive informal care than women and women are more likely to receive formal care. This is because men basically have wives, rather than women to have husbands and women live longer and on average have lower health status; thus require higher health care.[11]The results of the analysis show that income variable have a relationship with the utilization of health services. Income is all the income of family members that are calculated once a month. The income level affects the low utilization of health services. A high level of income will provide greater possibilities for utilizing health services. Revenue has an elastic nature to health services. [12] The public knows that in order to obtain a qualified and guaranteed health service is by paying, this results in the low utilization of health services.[13] Low income people who do not have sufficient social security are the most disadvantaged because they suffer not only from unstable income or poor health, but also from high payments for health care.[14]

The results of the analysis shoe that variable access to health services has a relationship with the utilization of health services. It is said that access to health services is difficult once the distance from the respondent's home to health services is $>5 \mathrm{~km}$ with a distance of $>30$ minutes. There is no relationship between the distance with the utilization of health services because the respondents are much more enthusiastic to go to health services. 15 The results of this study indicate that there is a relationship between access to health services with health service utilization as PWDs becoming respondents of the research are people with severe disability and need help from others to seek health services. PWDs experience obstacles in utilizing health services when health services are at a great distance. [16] The low utilization of health services is caused by the distance between health s ervices and the community that is too far in reaching health services, high health costs, unsatisfactory services and the perception of the community itself towards the concept of illness.[17]

The results of this study indicate that the variable costs of health services also have a relationship with the utilization of health services. There is a relationship between the cost of health services and the utilization of health services. The cost of health services is the amount of money that must be paid to those who provide health services, the fees paid are in accordance with the services received by patients such as the cost of health workers, medicines. Cost factors are constraints in utilizing health services, health services are available but health costs are not available so the community still cannot utilize health services. [18,19] In this study, the percentage of the cost of expensive health services is more utilizing health services, this is influenced by the positive attitude of respondents to health services also affect the utilization of health services. Another factor that supports the percentage of the cost of expensive health services is greater than the low cost of health, including the quality and quality of services provided and the need factor. 
Costs incurred in proportion to the quality and quality of services provided as well as their need (need) factors for health services also become one of the factors that influence the utilization of health services.

The results of the variable analysis indicate that the attitude has a relationship with the utilization of health services. Attitude variable is the most dominant variable influencing the utilization of health services. Attitude is a person's positive or negative response to a particular situation or object. Attitudes contain emotional or affective, judgments included in the emotional assessment which are happy, hateful and sad. The one belonging to cognitive is one's knowledge of the object being assessed. That which includes into the conative is the tendency to act. [20] A person's attitude can change with the acquisition of additional information about a particular object through the social group or surrounding environment. Attitudes are shaped by two factors, internal factors and external factors. Those included in the internal factors include: motives, interests, physiological conditions and other psychological aspects while those included in external factors include: norms, education and experience[21].

There is a relationship between attitudes and the utilization of health services. Attitudes and behavior are interrelated. But attitude is influenced by social norms and group pressure. Negative attitudes and behavior stem from people who lack adequate knowledge as well as negative social norms and group pressures. Negative attitudes from service providers can reduce service use and encourage low expectations by PWDs. [22.23] Attitudes are related to the act of utilization of health services and not necessarily materialized into action. To realize attitude into action, other chaining factors are required so that attitude manifest into action and knowledge and experience on health services are needed. In realizing the attitude of being an action, moreover, other supporting factors are needed, including the availability of health services, funding sources and health costs. If health services are available, the source of funds to pay for medical costs is also available and healthcare costs are also affordable then a positive attitude can be realized into action, namely the act of utilizing health services. [24] negative attitudes of healthcare providers may affect the utilization of health services as negative attitudes can encourage low expectations for PWDs, encourage discriminatory behavior and disable exclusionary exceptions for health providers themselves[25].

\section{Conclusion}

There is a relationship between variables of gender, income, access to health services, health care costs and attitudes towards utilization of health services. The variables that most influence the utilization of health services are positive attitudes towards health services. It is hoped the government review the existing infrastructure in health services so that the creation of situations and regions that are more friendly to people with disabilities.

\section{References}

1. World Health Organization. Disabilities. (WHO, 2015)

2. World Health Organization. Disability and Health. (WHO, 2015)

3. World Health Organization. 10 Facts on Disability. (WHO, 2017)

4. Lembaga Penyelidikan Ekonomi Masyarakat. Menuju pasar kerja yang inklusif bagi penyandang disabilitas di Indonesia (LPEM, 2016)

5. Dinas Sosial Kota Palembang. Data Penyandang disabilitas yang mendapat asistensi penyandang disabilitas berat di kota palembang (Dinsos Kota Palembang, 2017) 
6. Peraturan Daerah Sumatera Selatan. Undang - Undang No 6 Tahun 2014 Tentang Perlindungan dan Pelayanan Kesejahteraan Sosial bagi Penyandang Disabilitas. (Perda Sumsel, 2014)

7. Chen,M.C.,Kung, P.T., Su, H.P., Yen, S.M., Chiu,L.T., \& Tsai,W.C. International Journal for Equity in Health 15, 58 (2016)

8. Badu, E., Agyei-Baffour, P., \& Opoku, M. P. Canadian Journal of Disability Studies 5, 2 (2016)

9. Rumengan, D. S., Umboh, J. M. L., \& Kandou, G. D. JIKMU 5, 2 (2015).

10. Kung, Tsai W.C \& Li Y.H. 33, 1 (2015)

11. Garcia, J. R., Prieto-Flores, M. E., \& Rosenberg, M. W. Ageing and Society Journal 28, 7 ( 2008)

12. Wahyuni, Nanik Sri. Faktor-faktor yang berhubungan dengan pemanfaatan pelayanan kesehatan di Puskesmas Sumber Rejo Provinsi Kalimantan Timur. (Skripsi, 2012)

13. Napirah, M. R., Rahman, A., \& Tony, A. Jurnal Pengembangan Kota 4, 1 (2015)

14. Jeon, B., Noguchi, H., Kwon, S., Ito, T., \& Tamiya, N. 178, 8 (2017)

15. Logen, Y., \& Balqis, D. Determinan pemanfaatan pelayanan kesehatan oleh pemulung di TPA Tamangapa. (2015)

16. Nunik, Angela S.N.H, Kusuma E.W \& Safrina L. Keterbatasan akses bagi kaum disabilitas. (2016)

17. Notoadmojo, S. Ilmu perilaku kesehatan (Jakarta, Rineka Cipta, 2010)

18. Gudlavalleti, M. V. S., John, N., Allagh, K., Sagar, J., Kamalakannan, S., \& Ramachandra, S. S. BMJ Public Health 14, 1 (2014)

19. Syukria, O. A., \& Supriyanto, S. Jurnal Adminitrasi Indonesia 4, 1 (2016)

20. Maulana, Heri D. J. Promosi Kesehatan. (Jakarta, EGC, 2009)

21. Saam, Zulfan and Wahyuni, Sri. Psikologi Keperawatan. Jakarta: Rajawali Pers;2012.

22. Yunita,A. Jurnal Ilmu Kesehatan 2, 2 (2015)

23. Devkota, H. R., Murray, E., Kett, M., \& Groce, N. Reproductive Health 14 (2017)

24. Fratika, Pangemanan J.M \& Rumampuk J. Hubungan antara tingkat pengetahuan dan sikap masyarakat kelurahan imandi dengan tindakan pemanfaatan puskesmas imandi. (Manado, Universitas Sam Ratulangi, 2013)

25. Kleintjes, S., Lund, C. \& Swartz, L. BMC International Health and Human Rights 13, 17 (2013) 